\title{
Hen Egg Yolk Antibodies Purified by Antigen Affinity under Highly Alkaline Conditions Provide New Tools for Diagnostics. Human Intact Parathyrin as a Model Antigen
}

\author{
Ilpo Kuronen ${ }^{1}$, Harri Kokko ${ }^{2}$, Ilkka Mononen ${ }^{1}$ and Markku Parviainen ${ }^{1}$ \\ ${ }^{1}$ Department of Clinical Chemistry, Kuopio University Hospital, Kuopio, Finland \\ 2 Department of Biochemistry and Biotechnology, University of Kuopio, Kuopio, Finland
}

Summary: Hen egg yolks have been recognized as convenient source for specific antibodies, although their utility in diagnostic applications has been hampered by the lack of efficient purification methods. In the present study, anti-human parathyrin antibodies were raised in rabbits, hens and mice using synthetic human parathyrin peptide $(1-84)$ as an antigen. The antibodies were affinity purified with amino- $(1-30)$ and carboxy- (49-89) terminal peptides of parathyrin under highly alkaline elution conditions, and were evaluated for their diagnostic value in different combinations in immunoenzymometric assay (IEMA) format. A pair of hen egg yolk antibodies were subjected to further methodological validation in the IEMA that was constructed with the N-terminal capture and C-terminal detection antibodies. The synthetic intact human parathyrin $(1-84)$ peptide served as a standard. This within-day IEMA procedure turned out to be sensitive and it correlated well with the two independent intact parathyrin immunoradiometric assays. As shown in the present study, the immuno affinity purification with the highly alkaline elution conditions provides an efficient method for utilization of hen egg yolk antibodies. This is the first report on an application making use of a combination of two hen egg yolk antibody preparations in measuring a homogeneous protein in human serum.

\section{Introduction}

Hen egg yolk antibodies have aroused interest because of their fast, convenient and inexpensive manufacture when compared with mammalian antibodies. Because of these advantages together with some structural and functional properties, these antibodies have been examined as potential therapeutic proteins against some gastrointestinal pathogens. For diagnostic applications, avians as more distant phylogenetic species from mammals, may provide new epitopes especially for antigens of mammalian origin. Utility of the yolk antibodies has been hampered by the lack of efficient purification methods since many, especially diagnostic applications, require extremely pure antibody preparations. Crude extraction methods published so far produce almost homogeneous antibody preparations $(1,2)$ but to meet the quality requirements for being linked to solid supports only the purification methods based on antigen affinity are preferred. The acidic elution buffers detaching antibodies from their antigens tend to cause irreversible denaturation of especially egg yolk antibodies leading to reduced immunoreactivity and poor applicability of such antibodies. In this study we optimized the elution conditions based on highly alkaline buffer, $0.05 \mathrm{~mol} / \mathrm{l}$ diethylamine at $\mathrm{pH} 11.5$, for egg yolk antibodies raised against the synthetic peptides of human parathyrin. These antibodies together with the rabbit and mice antibodies also raised against the intact parathyrin peptide $(1-84)$ were investigated for their antigen binding properties with the direct and immunoenzymometric (IEMA) techniques. The IEMA making use of hen egg yolk antibodies which recognize epitopes at the opposite ends of the intact parathyrin polypeptide was subjected to methodological and analytical evaluation with samples from normal and hyperparathyroid subjects. As indicated in the present study, the affinity purification of the egg yolk antibodies under highly alkaline conditions produce reactive antibodies that could be utilized in the sensitive IEMA detecting intact human parathyrin with the performance well comparable with the presently available commercial assays. This IEMA provides sensitive non-radiometric within-day procedure for measuring human parathyrin in serum of plasma.

\section{Materials and Methods}

Materials and chemicals

The cell culture reagents and plastic ware were from Nunc (Roskilde, Denmark), the commercial antibodies and IEMA reagents were from Zymed (San Francisco, CA, USA), and the other chemicals were from Sigma (St Louis, MO, USA) unless otherwise stated. Synthetic peptides of human parathyrin $(1-30),(49-84)$ and $(1-84)$ were synthesised by EriLab Ltd, Kuopio, Finland. The peptides were app. $98 \%$ pure as confirmed by Edman degradation and mass spectrometric analysis. One milligram of the parathyrin (1-84, 1-30 and 49-84) peptides were linked to key hole limpets 
haemocyanin (KLH, Calbiochem, CA, USA) using the glutaraldehyde method (4) and stored in small aliquots at $-24^{\circ} \mathrm{C}$ until used for immunizations. The peptides were chosen on the basis of their physiological properties, which were determined from the amino acid sequence illustrating structural orientation and antigenicity $(5$, $6)$. The $(1-30)$ and $(49-84)$ peptide conjugates were used for titreing of the terminal specific antibodies. All the experimental animals were provided by the National Centre of Experimental Animals (University of Kuopio, Finland), and were treated according to the ethical standards set for experimental animals in Finland.

\section{Immunization}

For the monoclonal antibodies, Balb/c mice were immunized (i. p.) with $400 \mu \mathrm{g}$ of the key hole limpet haemocyanin-parathyrin $(1-84)$ conjugate in Freund's complete adjuvant, followed by four boosters given at four to five week intervals with the same amount of antigen in Freund's incomplete adjuvant. The hybridomas were prepared with the standard procedures using mouse P3X63-Ag8.53 myeloma cells (ATCC-CLR 1583, USA) as a fusion partner. For the polyclonal antibodies, rabbits (New Zealand White) and hens (Leghorn) were immunized (i. m.) with the key hole limpet haemocyanin-parathyrin $(1-84)$ conjugate, followed by four boosters given at three (rabbits) and two (hens) week intervals as above.

\section{Purification of antibodies}

Based on the titre analysis, the eggs laid between days 30-62 were chosen for the crude extraction of the egg yolk antibodies as described by Akita \& Nakai (1) and Kokko et al. (2). For the affinity purification of the rabbit immunosera, hybridoma media and the crude egg yolk extracts, $5 \mathrm{mg}$ of the parathyrin amino- and carboxy-terminal peptides were linked to $1 \mathrm{~g}$ of cyanogen bromide activated Sepharose CL 4 B (Pharmacia, Uppsala, Sweden) using the manufacturer's instructions. Crude egg yolk extract (100-200 $\mathrm{mg})$ in $20 \mathrm{ml}$ of phosphate-buffered saline $\left(0.05 \mathrm{~mol} / 1 \mathrm{Na}_{2} \mathrm{HPO}_{4}\right.$, $0.15 \mathrm{~mol} / 1 \mathrm{NaCl}, \mathrm{pH} 7.4), 5 \mathrm{ml}$ of the rabbit immunoserum diluted $1: 5$ with phosphate-buffered saline containing $20 \mathrm{mmol} / 1$ of EDTA, or $1000 \mathrm{ml}$ of the hybridoma media were passed through the column and the column was washed with phosphate-buffered saline until no detectable amount of protein emerged. Fractions of $1 \mathrm{ml}$ were collected using $0.05 \mathrm{~mol} / 1$ diethylamine, $\mathrm{pH} 11.5$, into tubes containing $100 \mu \mathrm{l}$ of $1 \mathrm{~mol} / \mathrm{l}$ Tris-HCl, $\mathrm{pH} 7.4$. The protein concentration of the purified antibody preparations was estimated according to absorption coefficients at $280 \mathrm{~nm} ; 13$ for $1 \%$ solution of mouse IgG, and 14 for $1 \%$ solution of hen egg yolk antibodies and rabbit IgG.

\section{Biotinylated antibodies}

The affinity purified antibodies were dialyzed against $0.1 \mathrm{~mol} / \mathrm{l}$

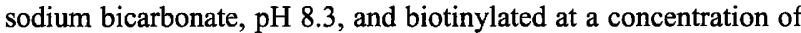
$1 \mathrm{~g} / 1$ using $10 \mu \mathrm{g}$ of biotin succinimide ester (Zymed, USA) per $1 \mathrm{mg}$ of protein, as described by Harlow \& Lane (7). After dialyzation with phosphate-buffered saline, $50 \mathrm{~g} / \mathrm{l}$ of bovine serum albu$\mathrm{min}, 20 \mathrm{mmol} / 1$ of EDTA and $0.5 \mathrm{~g} / 1$ of sodium azide as their final concentration were added for storage at $4{ }^{\circ} \mathrm{C}$. For these experiments, the egg yolk and the mouse IgM-class monoclonal antibodies reacting against the $(49-84)$ peptide were biotinylated.

\section{Standard}

Ten milligrams of the synthetic intact parathyrin peptide were solubilized with $10 \mathrm{ml}$ of $0.1 \mathrm{~mol} / 1$ sodium carbonate, $\mathrm{pH} 9.6$. For storage at $-24^{\circ} \mathrm{C}, 0.5 \mathrm{~g} / 1$ of sodium azide and $20 \mathrm{mmol} / 1$ of EDTA were added. The actual standard concentrations were prepared from the stock solutions by making stepwise dilutions. Repeated freezethawing of the standards was avoided.

\section{Serum samples}

Peripheral blood was drawn into ice-cold vacuum tubes and these were placed on ice immediately after sampling. After clotting, the serum was separated by centrifugation at $2000 \mathrm{~g}$ for $15 \mathrm{~min}$ at $4{ }^{\circ} \mathrm{C}$ and stored in small aliquots at $-20^{\circ} \mathrm{C}$ until analyzed. Parathyrin from the human serum was depleted by intensive dialysis against phosphate-buffered saline. All human material was treated according to ethical standards of Kuopio University Hospital, Finland.

\section{Parathyrin IEMA}

Polystyrene microtitration plates were coated overnight with 200 $\mu \mathrm{l}$ per well of capture antibodies in $0.1 \mathrm{~mol} / 1 \mathrm{Tris}-\mathrm{HCl}-0.15 \mathrm{~mol} / \mathrm{l}$

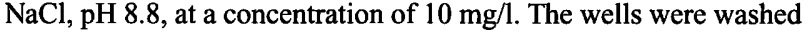
once with a washing buffer $(10 \mathrm{mmol} / \mathrm{l}$ Tris- $\mathrm{HCl}, 0.15 \mathrm{~mol} / \mathrm{l} \mathrm{NaCl}$, $0.5 \mathrm{ml} / 1$ Tween 20, $\mathrm{pH} 7.4$ ) and blocked with $10 \mathrm{~g} / \mathrm{l}$ bovine serum albumin in phosphate-buffered saline for 2 hours. The standards diluted with the assay buffer $(20 \mathrm{~g} / \mathrm{l}$ bovine serum albumin in phosphate-buffered saline, $20 \mathrm{mmol} / 1$ EDTA, $0.5 \mathrm{~g} / 1$ proclin, $0.5 \mathrm{ml} / 1$

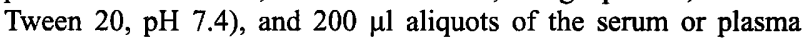
samples were added to the wells and incubated in a plate shaker at room temperature for four hours followed by washing five times with the washing buffer. Two hundred microlitres of the tracers were added to the wells and incubated for another hour at room temperature. After washing with the washing buffer, $200 \mu \mathrm{l}$ of streptavidin or species specific secondary antibodies conjugated to horse radish peroxidase were added and they were incubated for $1 \mathrm{~h}$ at room temperature. The wells were washed as above and developed with the peroxidase substrate (ABTS) and read at 405 $\mathrm{nm}$. The blanks included incubations with the assay buffer and the parathyrin-depleted human serum samples. The antibodies recognizing the $(1-30)$ peptide were used for coating. The coated plates remained stable for at least 3 months when stored carefully sealed under humid conditions at $4-8^{\circ} \mathrm{C}$. In the present experiments, the coated plates were used within 2 weeks.

\section{Other assays}

For comparative analysis of intact parathyrin, commercial IRMA methods from INCSTAR (N-test PTH, Incstar Laboratories, Stillwater, MN, USA) and Immunodiagnostic System (Gamma BCT Intact PTH, Boldon, UK) were used as recommended by the manufacturers.

\section{Results}

Earlier reports have indicated that the major antigenic site in human parathyrin lies in the carboxy-terminal end of the polypeptide, and only a poor or undetectable response is directed towards the amino- and mid-molecule sites. This was also found in the present investigation, since the mean titres of the amino- and carboxy-terminal specific antibodies in the mice $(\mathrm{n}=5)$ and rabbits $(n=3)$ sera were $1: 100$ and $1: 28000$ at their peak, respectively. Also, only the carboxy-terminal peptidespecific monoclonal antibodies of IgG and IgM classes were obtained. In contrast, positive reactions at very high dilutions were measured from the crude hen yolk extracts against both of the terminal peptides, peaking shortly after the second antigen exposure (four weeks after the first one). Optimally, up to $0.98 \mathrm{mg}$ and 1.12 $\mathrm{mg}$ of the specific antibodies were obtained from an egg yolk against the amino- and carboxy-terminal ends, respectively.

\section{Immunoaffinity chromatography}

For many applications, only affinity-pure quality of antibodies is acceptable. Hen egg yolk antibodies especially are vulnerable to irreversible denaturation and loss of their biological activity in acidic conditions (3). As 
shown in figure 1, acidic elution buffers at the $\mathrm{pH}$ scale from 3.5 to 4.0 were able to detach the antigen-antibody complex but caused irreversible denaturation and loss of the biological activity of the hen egg yolk antibodies. Instead, the alkaline elution buffer, $0.05 \mathrm{~mol} / 1$ diethylamine at $\mathrm{pH} 11.5$, eluted the bound antibodies sharply and preserved their binding activity.

\section{Development of the parathyrin IEMA}

Although several antibody combinations tested in an IEMA format reacted specifically against the intact parathyrin, the construct of affinity purified hen antiparathyrin $(1-30)$ for the capture and the biotinylated hen anti-parathyrin $(49-84)$ for the detection gave the best assay sensitivity and resolution (fig. 2). This construct was further evaluated for assay performance.

The typical standard profile of this IEMA is shown in figure 3. The curve represents the mean values $(n=3)$ of three assays done on consecutive days. As calculated from the data, the theoretical limit of detection is 1.23 $\mathrm{ng} / \mathrm{l}\left(3 \mathrm{SD}_{\text {blank }}+\right.$ blank, $\left.\mathrm{n}=10\right)$. The analytical limit of detection defined with a normal human serum after stepwise dilution was $2.4 \mathrm{ng} / 1$ (fig. 4).

Intra-assay variation determined with five human serum samples varied from 2.3 to $9.2 \mathrm{CV} \%$ (mean $7.1 \%$, tab. 1) at the parathyrin concentration of $7.5-211 \mathrm{ng} / 1$. Interassay variation determined with the same samples varied from 6.6 to $10.2 \mathrm{CV} \%$ (mean $9.1 \%$; tab. 1). The assay imprecision at a very low level $(2.5 \mathrm{ng} / \mathrm{l})$ was 17.2 and 19.2 CV\% (tab. 1).

Analytical recovery after the addition of a known amount of the synthetic parathyrin (1-84) standard pep-

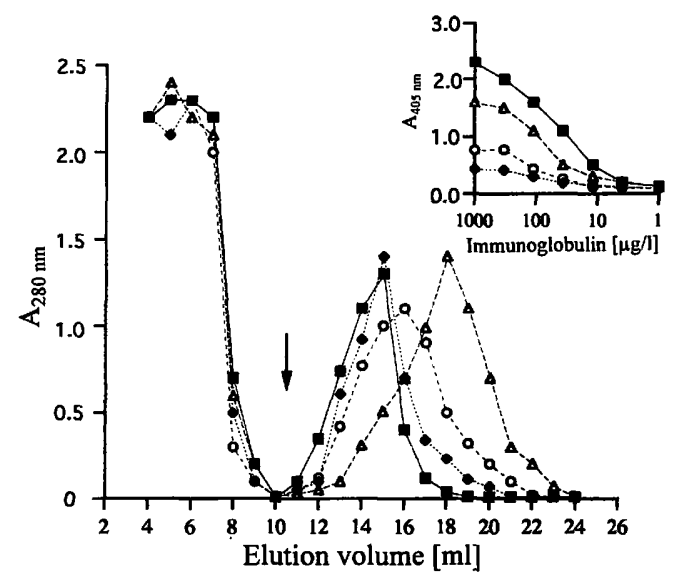

Fig. 1 Elution diagrams and reactivity of the anti-parathyrin $49-84$ egg yolk antibody using $0.05 \mathrm{~mol} / 1$ of diethylamine, $\mathrm{pH} 11.5$ (घ), (2) $0.05 \mathrm{~mol} / \mathrm{l}$ of glycine, $\mathrm{pH} 4.0(\diamond)$, (3) $0.05 \mathrm{~mol} / 1$ of glycine, $\mathrm{pH} 3.5(0)$, and (4) $0.05 \mathrm{~mol} / \mathrm{l}$ of glycine, $\mathrm{pH} 3.8(\triangle)$, as elution buffers. The affinity purification was done as described in the Methods. The reactivity of the purified antibodies was measured by direct ELISA against the parathyrin $(1-84)$ polypeptide using stepwise dilutions from the pooled antibody preparations containing equal concentration of antibodies. The arrow indicates the point of starting the eluation with the buffers mentioned above.

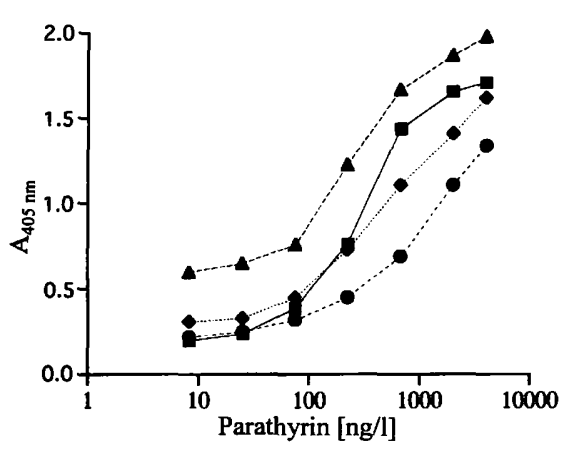

Fig. 2 Utility of the purified antibodies to detect the parathyrin $(1-84)$ polypeptide in IEMA format was tested in different combinations. The IEMA was done as described in the text using the following combinations: the egg yolk antibody against the $(1-30)$ peptide for capture and the biotinylated egg yolk antibody against the (49-84) peptide for detection ( $\square$ ), the egg yolk antibody against the $(1-30)$ peptide for capture and the rabbit antibody against the 49-84 peptide for detection ( $\bullet$ ), the egg yolk antibody against the $(1-30)$ peptide for capture and the mouse monoclonal (IgG-class) antibody against the (49-84) peptide for detection $(\bullet)$, the mouse monoclonal (IgG-class) antibody against the (49-84) peptide for capture and the biotinylated mouse monoclonal (IgMclass) antibody against the $(1-30)$ peptide for detection $(\Delta)$. The reactions were detected with species-specific antibodies (horse radish peroxidase-conjugates), or with streptavidin horse radish peroxidase conjugate (biotinylated antibodies). Each point is the mean value of three analyses.

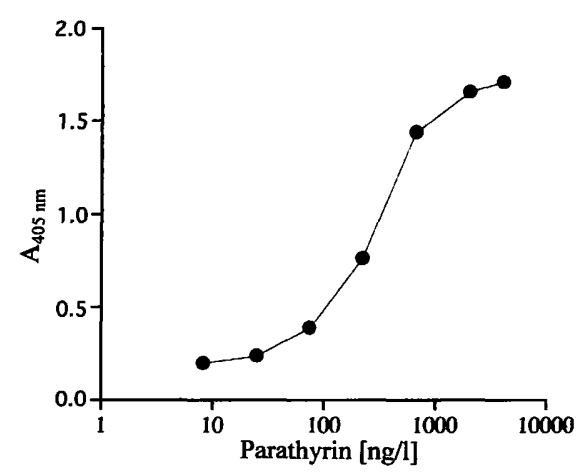

Fig. 3 A typical standard profile $(n=3)$ of the intact parathyrin IEMA showing the linear measuring range on a semilogarithmic scale.

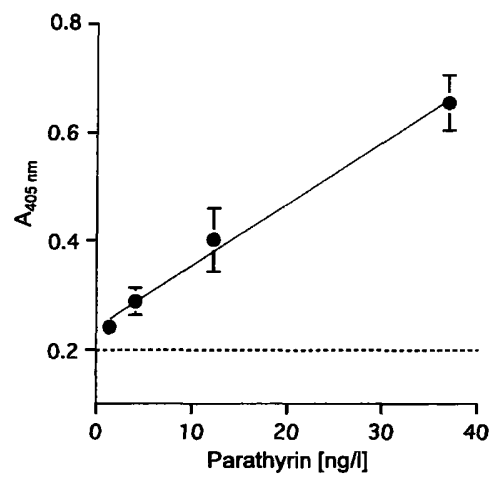

Fig. 4 The limit of detection analysed after serial dilution of human serum sample $(n=3)$, with the assay buffer containing $25 \%$ (as final concentration) of the parathyrin-depleted human serum. The dashed line represents the absorbance mean value of three blank reactions (absorbance mean $=0.209, \mathrm{SD}=0.014$ ). 
tide into human serum varied from $82 \%$ to $116 \%$ (mean $99.1 \% ; \mathrm{n}=7$ ), and after serial dilution with the parathyrin-depleted serum from $91 \%$ to $108 \%$ (mean $101.6 \% ; \mathrm{n}=9$, tab. 2).

Neither the standard peptide after trypsin digestion nor the amino- or carboxy-terminal peptide of the human parathyrin produced positive reaction in the IEMA (fig. $5)$. The $(1-84)$ polypeptide used as a standard for the

Tab. 1 Imprecision of the parathyrin IEMA.

\begin{tabular}{llllllll}
\hline Sample number & 1 & 2 & 3 & 4 & 5 & 6 \\
\hline $\begin{array}{l}\text { Intra-assay imprecision } \\
\begin{array}{l}\text { Mean of } \\
9 \text { replicates [ng/l] }\end{array}\end{array}$ & 7.5 & 15.6 & 30.4 & 100.6 & 210.8 & 2.43 \\
$\begin{array}{l}\text { Coefficient of } \\
\text { variation (\%) }\end{array}$ & 9.2 & 7.5 & 2.4 & 4.2 & 2.3 & 17.2 \\
$\begin{array}{l}\text { Inter-assay imprecision } \\
\text { Mean of } \\
4 \text { replicates [ng/l] }\end{array}$ & 7.9 & 12.5 & 28.4 & 102.5 & 197.8 & 2.67 \\
$\begin{array}{l}\text { Coefficient of } \\
\text { variation (\%) }\end{array}$ & 6.6 & 10.5 & 5.2 & 7.1 & 6.3 & 19.2 \\
\hline
\end{tabular}

Tab. 2 Analytical recovery of the parathyrin IEMA.

\begin{tabular}{llll}
\multicolumn{4}{l}{ A. After serial dilution of human serum } \\
\hline a Dilution & $\begin{array}{l}\text { Calculated } \\
\text { concentration }\end{array}$ & $\begin{array}{l}\text { Analyzed } \\
\text { concentration }\end{array}$ & Recovery \\
& {$[\mathrm{ng} / \mathrm{l}]$} & {$[\mathrm{ng} / \mathrm{l}]$} & {$[\%]$} \\
\hline 1 & 374 & 366 & 97.8 \\
$1: 2$ & 187 & 192 & 104.8 \\
$1: 4$ & 93.5 & 91.1 & 97.4 \\
$1: 8$ & 46.8 & 49.9 & 106.6 \\
$1: 16$ & 23.4 & 19.2 & 82.1 \\
$1: 32$ & 11.6 & 10.3 & 88.8 \\
$1: 64$ & 5.53 & 6.41 & 115.9 \\
\hline
\end{tabular}

Mean

99.1

a Parathyrin-depleted human serum in the assay buffer $(1: 4)$ was used as a diluter.

B. After addition of standard to human serum

\begin{tabular}{lclc}
\hline${ }^{b}$ Base & $\begin{array}{l}\text { Added } \\
\text { amount } \\
{[\mathrm{ng} / \mathrm{l}]}\end{array}$ & $\begin{array}{l}\text { Analyzed } \\
\text { amount } \\
{[\mathrm{ng} / \mathrm{l}]}\end{array}$ & $\begin{array}{l}\text { Recovery } \\
{[\%]}\end{array}$ \\
\hline 4.6 & 1.23 & 6.21 & 106.5 \\
4.6 & 2.46 & 6.98 & 98.8 \\
4.6 & 4.92 & 10.3 & 108.2 \\
4.6 & 9.84 & 13.2 & 91.4 \\
4.6 & 19.7 & 26.4 & 108.6 \\
4.6 & 39.6 & 43.7 & 98.9 \\
4.6 & 79.2 & 87.7 & 104.7 \\
4.6 & 98.4 & 101.3 & 98.3 \\
4.6 & 196.8 & 199.4 & 99.0 \\
\hline Mean & & & 101.6 \\
\hline
\end{tabular}

b Mean concentration of the human serum (SD 0.12, $n=3$ ).
Gamma BCT Intact PTH IRMA reacted with a slightly lower affinity from our own standard, giving a standard profile as shown in figure 5. Human serum stored at room temperature for several days or dialyzed intensively against phosphate-buffered saline failed to react positively in the parathyrin IEMA, suggesting the specificity of the assay against intact or almost intact parathyrin.

Comparison of the present IEMA with the commercial methods for intact parathyrin showed a strong correlation, $\mathrm{r}=0.980(\mathrm{p}<0.001 ; \mathrm{n}=40 ; \mathrm{y}=15.58+0.69 \mathrm{x})$ with N-tact PTH IRMA, and $\mathrm{r}=0.965(\mathrm{p}<0.0001$; $\mathrm{n}=68 ; \mathrm{y}=-1.72+0.87 \mathrm{x})$ with Gamma BCT Intact PTH IRMA.

The tentative reference range, as analysed with 72 serum samples donated by subjects ( 26 men of ages $12-60$ a and 46 women of ages 7-49a) having no known disorders affecting the concentrations of parathyrin in systemic circulation, was $9.6-64.7 \mathrm{ng} / 1$ (at $95 \%$ confidence level).

In a follow-up study, we measured the level of intact parathyrin and total calcium in the serum of two patients who suffered from secondary hyperparathyroidism, before and after partial parathyroidectomy. Shortly after the operation, the earlier elevated level of intact parathyrin had fallen to normal concentration, or was even undetectable by the comparison method, leading to normalization of total calcium in the serum of these patients (fig. 6).

\section{Discussion}

Along with the development of more gentle and efficient purification techniques for hen egg yolk immunoglobulins, hens as a source for specific immunoglobulins have arisen interest because of their extremely high productivity and also because hens make it easier to satisfy

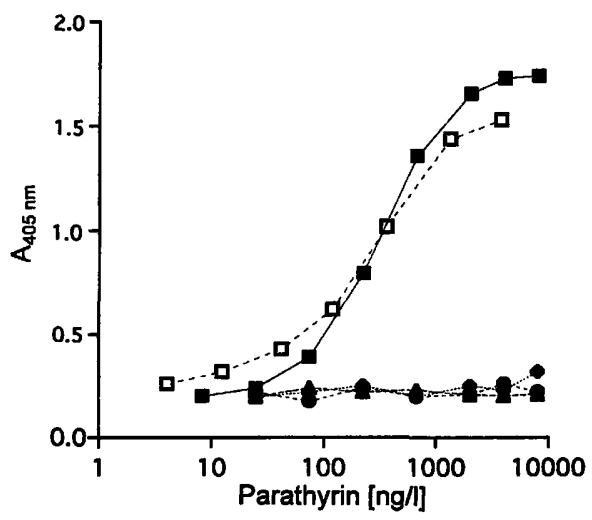

Fig. 5 Reactivity of the different parathyrin peptides in the present IEMA. In this figure, the 1-84 peptide ( $\square$ ), the 49-84 peptide $(\diamond)$, the $1-30$ peptide $(\bullet)$, the trypsin digestion of the 1-84 peptide $(\Delta)$, and the standards of the Gamma BCT Intact PTH IRMA, Immunodiagnostic Systems ( $\square$ ) are shown. 


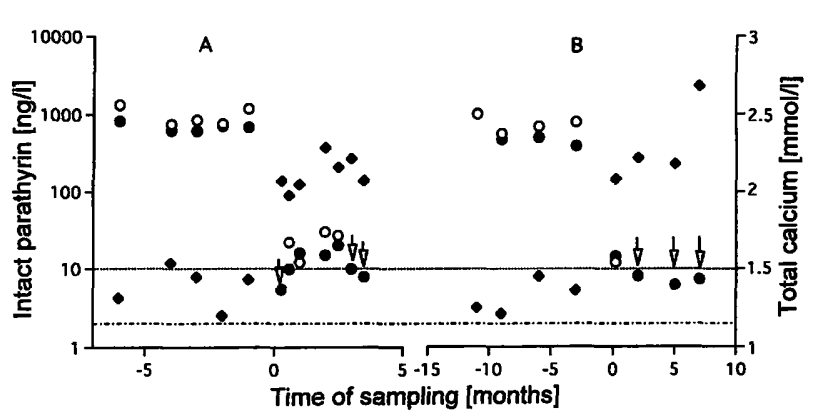

Fig. 6 Intact parathyrin and calcium $(\diamond)$ concentrations before and after parathyroidectomy (time $=0$ ) in the serum from the two patients with secondary hyperparathyroidism (A and B). The intact parathyrin was measured with the Gamma BCT Intact PTH IRMA (Immunodiagnostic Systems, U. K. (O)) and the present intact parathyrin IEMA (๑). The lowest detectable concentrations for the assays were $10 \mathrm{ng} / 1$ and $4.9 \mathrm{ng} / \mathrm{l}$, respectively (shown by the dashed lines where the lower line represents the one for the present IEMA). The assay results below the lowest detectable concentration obtained with the Gamma BCT Intact PTH IRMA are shown by arrows. The samples were run in duplicate as described in the Methods.

the legal requirements for experimental animals. As distant phylogenetic relatives of mammals, avians may provide new epitopes, especially for antigens from mammalian origin. As shown in the present study, the $(1-84)$ polypeptide that was used as antigen raised antibodies only against the carboxy-terminal site of the protein in the rabbits and mice, while only poor responses were found against the amino terminal parts. Conversely, the hens raised almost equal antibody response against both the $\mathrm{N}$ - and $\mathrm{C}$-terminal sites of parathyrin. By using the alkaline elution buffer in immunoaffinity chromatography, we obtained up to milligram quantity highly reactive site specific antibodies from each egg yolk. As found in our previous studies $(8,9)$, also rabbit and even mouse IgM-class antibodies preserved well their antigen binding ability with this technique. Although hen serum antibodies have been previously utilized in radioimmunometric parathyrin assay (10) and as a detection antibody in immunoradiometric parathyrin assay, the yolk antibody technology offers more inexpensive and convenient source of antibodies for parathyrin assays.

All the different antibody combinations used to measure intact parathyrin in the IEMA format gave slightly different reaction specificity and sensitivity. The IEMA with the best combination, the hen anti-parathyrin
$(1-30)$ for capture and the biotinylated hen anti-parathyrin (49-84) for detection, was very well comparable to the other radiometric or chemiluminometric assays developed for intact parathyrin in respect of assay performance, showing a strong correlation with the commercial radiometric assays. The difference in reactivity between the parathyrin standards in our IEMA (fig. 5) was probably due to different assay matrices, since the standards for the IRMA were prepared in swine serum. The matrix effect and the different standard preparations have been previously shown to affect the parathyrin assays (11).

Determination of the parathyrin concentration in systemic circulation is utilized in the diagnostics of physiological disorders related to altered parathyroid gland function and calcium ion balance in the body $(12-14)$. Numerous immunometric methods for the determination of circulating parathyrin have been developed with specificity to the biologically active aminoterminal sequence $(1-34)(15)$, the enzymatic cleavage site at $(44-68)$ $(16,17)$ or the intact polypeptide $(1-84)(18,19)$, but methods using two different antibody preparations directed against opposite ends of the parathyrin polypeptide are preferred because of their superior assay performance and clinical utility $(20,21)$. The present IEMA using the new hen egg yolk antibodies offers a very sensitive non-radioactive tool for the determination of the intact human parathyrin, even at levels well below the lower limit of the currently established normal range (fig. 6). So far, only a few methods performing sensitivity below $10 \mathrm{ng} / \mathrm{l}$ have been developed with chemiluminiscence or radioiodine detection (22-23). In terms of sensitivity and all other analytical properties, our IEMA is comparable to those methods, but it offers the advantage of requiring relatively inexpensive laboratory instrumentation. The diagnostic utility of the present IEMA in the parathyrin-related disorders is under further examination.

\section{Acknowledgements}

This study was funded by Special Laboratory EriLab Ltd., Kuopio, FIN-70210, Finland, The Sigrid Juselius Foundation, Finland, and the Savo Foundation For High Technology, Kuopio, Finland. The authors are grateful to Kari Savolainen, Ph. D., and Olavi Kajander, M. D., for their valuable comments, and to Ms. Eila Pirinen for her technical help.

\section{References}

1. Akita EM, Nakai S. Comparison of four purification methods for the production of immunoglobulins from hen eggs laid by hens immunized with an enterotoxigenic $E$, coli strain. J Immunol Meth 1993; 160:207-14.

2. Kokko H, Kuronen I, Kärenlampi S. Rapid production of antibodies in chicken and isolation from eggs. In: Celis J, editor. Cell biology: a laboratory handbook. Academic Press 1995:282-8.

3. Shimizu M, Nagashima H, Sano K, Hashimoto K, Ozeki K, Hatta $\mathrm{H}$. Molecular stability of chicken and rabbit immunoglobulin G. Biol Biotechnol Biochem 1992; 56:270-4.

4. Harlow E, Lane D, editors. Antibodies: a laboratory manual. Cold Spring Harbor, New York: Cold Spring Harbor Laboratory, 1988:81. 
5. Jameson BA, Wolf $\mathrm{H}$. The antigenic index: a novel algorithm for predicting antigenic determinants. Comput Appl Biosci $1988 ; 4: 181-6$.

6. Kyte J, Doolitte RF. A simple method for displaying the hydropathic character of a protein. J Mol Biol 1982; 157:10532.

7. Harlow E, Lane D, editors. Antibodies, a laboratory manual. Cold Spring Harbor, New Nork: Cold Spring Harbor Laboratory, 1988:341.

8. Kuronen I, Kokko H, Parviainen M. Production of monoclonal and polyclonal antibodies against synthetic human osteocalcin sequences and development of two-site ELISA for intact human osteocalcin. J Immunol Meth 1993; 163:233-40.

9. Parviainen M, Kuronen I, Kokko H, Lakaniemi M, Savolainen $\mathrm{K}$, Mononen I. Two-site enzyme immunoassay for measuring intact human osteocalcin. J Bone Mineral Res 1994; 9:34753.

10. Gallagher JC, Riggas BL, Jerpbak CM, Arnaud CD. The effect of age on serum immunoreactive parathyroid hormone in normal and osteoporotic women. J Lab Clin Med 1970; 95(3):373-85.

11. Withold W, Schallenberg A, Reinauer H. Performance characteristics of different immunoassays for determination of parathyrin $(1-84)$ in human plasma samples. Eur J Clin Chem Clin Biochem 1995; 33:307-13.

12. Lufkin EG, Kao PC, Heath HH. Parathyroid hormone radioimmunoassays in the differential diagnosis of hypercalcemia and due to primary hyperparathyroidism or malignancy. Ann Intern Med 1987; 106:559-60.

13. Vargas SJ, Diez-Morales LF, Jones TG, Froesch TA, Hurley MM, Raisz LG. Comparison of commercially available parathyroid hormone immunoassays in the differential diagnosis of hypercalcemia. Am J Med Sci 1987; 294:13.

14. Ashby JP, Thakkar H. Diagnostic limitations of region-specific parathyroid hormone assays in the investigation of hypercalcemia. Ann Clin Biochem 1988; 25:275-9.

15. Mallette LE, Tuma SN, Berger E, Kirkland JL. Radioimmunoassay for the middle region of human parathyroid hormone using an homologous antiserum with a carboxy-terminal fragment of bovine parathyroid hormone as radioligand. J Clin Endocrinol Metab 1982; 54:1017-24.
16. Marx SJ, Sharp ME, Kurdy A, Rosenblatt M, Mallette LE. Radioimmunoassay for the middle region of human parathyroid hormone: studies with a radioiodonated synthetic peptide. J Clin Endocrinol Metab 1981; 53:76-84.

17. Bouillon R, Coopmans W, Degroote DEH, Radoux D, Eliard PH. Immunoradiometric assay of parathyrin with polyclonal and monoclonal antibodies. Clin Chem 1990; 36:271-6.

18. Nussbaum SR, Zahradnik RJ, Lavigne JR. Highly sensitive two-site immunoradiometric assay of parathyrin and its clinical utility in evaluating patients with hypercalcemia. Clin Chem 1987; 33:1364-7.

19. Brown RC, Aston JP, Weeks I, Woodhead JS. Circulating intact parathyroid hormone measured by a two-site immunochemiluminometric assay. J Clin Endocrinol Metab 1987; 65:407-14.

20. Minisola S, Scarnecchia L, Romagnoli E, Carnevale V, Pacitti MT, Sorrada A, et al. Conventional and new diagnostic applications of a two-site immunochemiluminometric assay for parathyroid hormone. J Endocrinol Invest 1992; 15:483-9.

21. Nussbaum SR, Potts JT. Immunoassays for parathyroid hormone $(1-84)$ in the diagnosis of hyperparathyroidism. J Bone Mineral Res 1991; 20 Suppl 6:43-50.

22. St Jones A, Davies R, Riley WJ. Comparison of the performance and utility of a carboxy-terminal and an intact assay for parathyroid hormone. Clin Chim Acta 1988; 178:215-23.

23. Endres DB, Villanueva R, Sharp FS Jr, Singer FR. Immunochemiluminometric and immunoradiometric determination of intact and total immunoreactive parathyrin. Performance in the differential diagnosis of hypercalcemia and hypoparathyreodism. Clin Chem 1991; 372:162-8.

Received January 31/March 26, 1997

Corresponding author: Ilpo Kuronen, Department of Clinical Chemistry, Kuopio University Hospital, P. O. Box 1777, Kuopio, FIN-70210, Finland

fax:+358-17-2828752, e-mail: kuronen@messi.uku.fi 